\title{
Conservation, Phytoremediation Potential and Invasiveness Status of Bali Botanic Garden Aquatic Plant Collection
}

\author{
Farid Kuswantoro ${ }^{1 *}$
}

1) Research Center for Plant Conservation and Botanic Garden, Bali Botanic Garden, Indonesian Institute of Sciences, Candikuning Baturiti-Tabanan Bali, 82191

Submitted: 04 September 2019; Accepted: 03 January 2020; Published: 15 April 2020

\begin{abstract}
Bali Botanic Garden (BBG) aspires to conduct conservation and research of eastern Indonesian plant species, including the aquatic plant species. These were important as aquatic plant species could be ecologically threatened, beneficial or even dangerous. As scientific data of BBG aquatic plant species collection was limited, we proposed this study to provide researchers and garden managers with data to conduct research, collection and maintenance of the garden aquatic plant collection. The study was carried out by sourcing list of BBG collected plant species data for its aquatic plant species. Literatures study was then carried out to gain information regarding the plant species' heavy metal phytoremediation, conservation and invasiveness status while data analysis was conducted descriptively. The study result showed that 38 collection numbers of aquatic plant species collected in BGG were placed in five sites within the garden with $94 \%$ of all the aquatic plants collection came from Lesser Sunda Islands. Eleven aquatic plants species were listed as Least Concern by IUCN Red List. Fourteen species of collected aquatic plants were proved to possessed phytoremediation potential toward numerous heavy metal pollutants, while six species were listed as an invasive alien plant species in Indonesia. All of the provided data should be enabled the botanic garden stakeholders to come up with ideas in the research and maintenance effort of BBG aquatic plant collection.
\end{abstract}

Keywords: aquatic plant, botanic garden, conservation, heavy metal, invasive

\section{INTRODUCTION}

Aquatic plants species were an important constituent of the wetland ecosystem (Lacoul and Freedman, 2006). Evidence of the statement could be found in a study by Ismail et al. (2018) and Jha (2013) that stated the importance of the aquatic plant to influence the fish population, as well as food sources for numerous bird species. The importance of aquatic plant species for the ecosystem was not limited as shelter and food provider, but also to eliminate environmental pollutant known as phytoremediation (Peuke and Rennenberg, 2005). Alkorta and Garbisu (2001) study shows that good organic remediation result from plant species has drawn people attention to phytoremediation. Furthermore, Sumiahadi and Acar (2018) have listed several crop plants species including aquatic plant

\footnotetext{
*Corresponding author

Tel.: +6285225255211

Email: faridkuswantoro@ymail.com,fari006@lipi.go.id

(C) 2020, J. Tropical Biodiversity Biotechnology (CC BY-SA 4.0)
}

species as Pistia stratiotes and Eichhornia crassipes were already assessed for its phytoremediation potential toward heavy metal pollutant

Despite all of its environmental importance, some aquatic plant species may also treat the ecosystem as they were considered as invasive alien plant species. Hulme (2011) described alien species as an organism that present beyond its past or present origin area and dispersal potential and invasiveness as the establishment of those alien species which caused a detrimental effect on its new region. The presence of invasive aquatic plant species could not be overlooked as it could decrease the wetland yield and services as well as altering its cycle and chemistry (Keller et al., 2018). Invasive aquatic plant species induced environmental change was evidenced in the presence of Myriophyllum aquaticum that decreased the Dissolve Oxygen level and was in correlation with the diversity of epiphytic invertebrates and alien fish species (Kuehne et al., 2016). Hydrilla verticillata, E. crassipes, P. stratiotes, 
Mimosa pigra and Salvinia molesta were listed as Indonesian important aquatic invasive alien plant species (Tjitrosoedirdjo, 2005).

Although of all the above-mentioned facts, numerous aquatic plant species were threatened to extinction. In Europe for example, one aquatic plant species namely Trapa annosa was ranked as Extinct while five other aquatic plant species were ranked as Critically Endangered, eight species listed as Endangered and 13 species considered as Vulnerable by IUCN Red List (Bilz et al., 2011). Bali Botanic Garden (BBG) as an ex-situ conservation site has collected 22.432 plant specimens with 9.037 collection-number which some of them were aquatic plant species. Besides the living specimens, the garden collection was boosted even more by numerous amounts of herbarium, seed and nursery collection. However, scientific study regarding BBG aquatic plant species collection was scarce. Thus we propose this study to fill the gap. This study aims to describe aquatic plant species conservation in BBG as well as its phytoremediation potential to heavy metals pollutants and invasive status. We believe that the study result will offer baseline data for collection -based research of BBG aquatic plant species as well as enabled the garden manager to conduct researchbased collection and management of the aquatic plant species.

\section{MATERIALS AND METHODS}

\section{Materials}

The latest list of plant species collected in BBG (July 2019) were acquired from BBG Registration Unit. The online database of The Plant List (2013) and IUCN (2019) were used to determine the scientific name of the plant species and conservation status. Setyawati et al. (2015) and Tjitrosoedirdjo et al. (2016) were used to determine the invasiveness status of the aquatic plant species in Indonesia. Various scientific publications were also consulted to gain information regarding the plant species phytoremediation potential. The comparison of BBG aquatic plant collection and Purwodadi Botanic Garden (PBG) aquatic plant collection acquired from Puspitasari and Irawanto (2016) was also conducted.

\section{Methods}

The acquired list of plant species collection in BBG was sourced for the garden aquatic plant species collection. Obtained aquatic plant species data was then matched with The Plant List (2013) website online source to verify each plant species binomial names while IUCN (2019) website online source was consulted to acquire the plant species conservation status. Numerous scientific literatures available on the internet was then sourced for the aquatic plant species phytoremediation potential. Setyawati et al. (2015) and Tjitrosoedirdjo et al. (2016) studies were also sourced to provide the invasiveness status of BBG aquatic plant species in Indonesia. All of the acquired data were then analyzed and presented descriptively as tables, charts and figures. Jaccard Similarity Index (JSI) was used to compare aquatic plant collection identified until its species-level collected in BBG and PBG, and calculated following Mueller-Dombois and Ellenberg (2016) as follows:

$\mathrm{JSI}=\frac{\mathrm{A}}{\mathrm{A}+\mathrm{B}+\mathrm{C}} \times 100 \%$

$\mathrm{A}=$ Common species

$\mathrm{B}=$ Unique species in $\mathrm{BBG}$

$\mathrm{C}=$ Unique species in $\mathrm{PBG}$

\section{RESULTS AND DISCUSSION}

\section{Aquatic Plant Conservation in BBG}

Currently, BBG conserves 38 collection number of aquatic plants, consisting of 12 families. Complete aquatic plant taxa collected by BBG presented in Table $1 . \mathrm{BBG}$ aquatic plant collection was placed in five locations within the garden. Separated

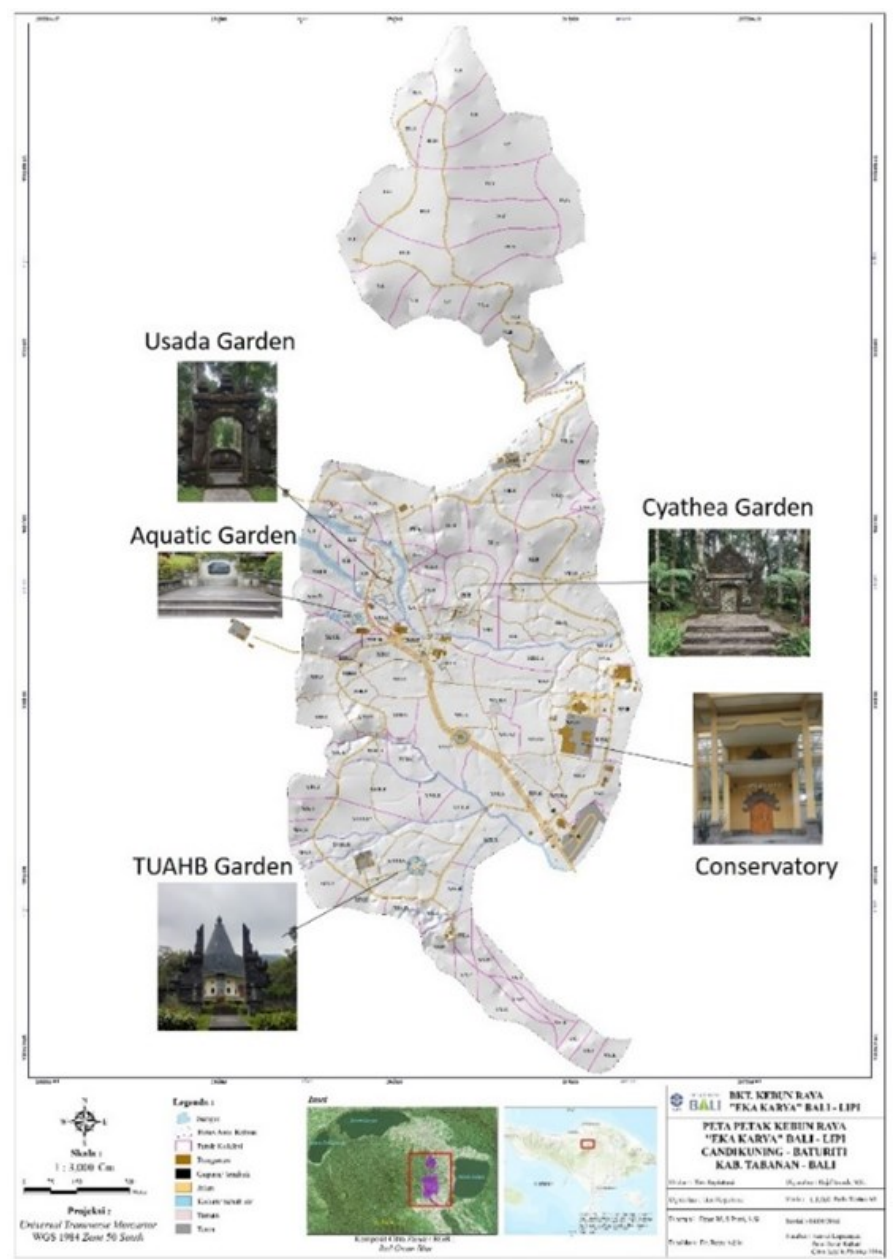

Figure 1. Aquatic Plant Species Location in BBG (CBali botanic Garden) 
Table 1. Aquatic Plant Taxa Collected by BBG

\begin{tabular}{|c|c|c|}
\hline Species Name & Location & Origin \\
\hline \multicolumn{3}{|l|}{ Acanthaceae } \\
\hline Acanthus ebracteatus Vahl & Usada Garden & Bali \\
\hline $\begin{array}{l}\text { Acanthus ilicifolius } \mathrm{L} \text {. } \\
\text { Acoraceae }\end{array}$ & Usada Garden & Bali \\
\hline $\begin{array}{l}\text { Acorus calamus } \mathrm{L} \text {. } \\
\text { Alismataceae }\end{array}$ & Aquatic Garden, TUAHB Garden & Bali, Timor \\
\hline $\begin{array}{l}\text { Sagittaria lancifolia } \mathrm{L} \text {. } \\
\text { Araceae }\end{array}$ & Araceae & Bali \\
\hline Cyrtosperma beccarianum A. Hay & Conservatory & Papua \\
\hline Cyrtosperma sp. & Conservatory & Bali \\
\hline Pistia stratiotes $\mathrm{L}$. & Aquatic Garden & Bali \\
\hline \multicolumn{3}{|l|}{ Cyperaceae } \\
\hline Cyperus involucratus Rottb. & Aquatic Garden & Bali \\
\hline Cyperus papyrus L. & Aquatic Garden & Bali \\
\hline Cyperus haspan $\mathrm{L}$. & Aquatic Garden & Bali \\
\hline Cyperus sp. & Aquatic Garden & Sumba \\
\hline Cyperus sp. & Aquatic Garden & Papua (Waigeo Is.) \\
\hline Cyperus sp. & Aquatic Garden & Bali \\
\hline Fimbristylis umbellaris (Lam.) Vahl & Aquatic Garden & Bali \\
\hline $\begin{array}{l}\text { Schoenoplectiella mucronata (L.) J.Jung \& H.K.Choi } \\
\text { Haloragaceae }\end{array}$ & Aquatic Garden & Sumba \\
\hline $\begin{array}{l}\text { Myriophyllum aquaticum (Vell.) Verdc. } \\
\text { Marsileaceae }\end{array}$ & Aquatic Garden & Bali \\
\hline $\begin{array}{l}\text { Marsilea polycarpa Hook. \& Grev. } \\
\text { Menyanthaceae }\end{array}$ & Cyathea Garden & Bali \\
\hline Nymphoides indica (L.) Kuntze & Aquatic Garden & Bali \\
\hline \multicolumn{3}{|l|}{ Nymphaeaceae } \\
\hline Nymphaea elleniae S.W.L. Jacobs & Aquatic Garden & Bali \\
\hline Nymphaea "Mrs. C.W. Word" & Aquatic Garden & Bali \\
\hline Nymphaea pubescens Willd. & Aquatic Garden & Bali \\
\hline \multicolumn{3}{|l|}{ Pontederiaceae } \\
\hline Eichornia crassipes (Mart.) Solms & Aquatic Garden & Bali \\
\hline Pontederia cordata $\mathrm{L}$. & Aquatic Garden & Bali \\
\hline \multicolumn{3}{|l|}{ Salviniaceae } \\
\hline Azolla pinnata R.Br. & Cyathea Garden & Bali \\
\hline Salvinia adnata Desv. & Cyathea Garden & Bali \\
\hline \multicolumn{3}{|l|}{ Thypaceae } \\
\hline Typha angustifolia $\mathrm{L}$. & Aquatic Garden & Bali \\
\hline
\end{tabular}

placement of aquatic plant specimens in BBG was possible since Indonesian Botanic Garden arranged its collection placement based on the plant taxonomy, utilization, origin and another category or its combination (Hadimuljono et al., 2014). In case of BBG aquatic plant species, most of the specimen was placed based on its habitus similarity at the Aquatic Garden while some of the others were placed based on its taxonomy and utilization. Species that were placed based on its taxonomical status were the A.pinnata, M. polycarpa and S. adnata which placed in Cyathea Garden which contain fern collection of BBG (Figure 1). Aquatic plant species that placed based on its utilization as medical plant were the $A$. ebracteatus and A. ilicifolius, those were placed in Usada Garden which contain Balinese traditional medicinal plant species (Figure 1). Another plant species that placed based on its utilization was the $A$. calamus which also placed in Taman Upacara Adat Hindu Bali (TUAHB) Garden which contains plant species utilized for the Balinese Hindu ceremony due to its ceremonial use (Figure 1). Another aquatic plant species placed outside the Aquatic Garden was Cyrtosperma beccarianum which placed in the Conservatory as representative of the aquatic plant species, Conservatory purpose was to describe the plant species evolution process.

BBG Aquatic Garden was the garden primary site to conserve its aquatic plant specimen with $71 \%$ of all the aquatic plant collection number placed in the site (Figure 2). This was not surprising as the Aquatic Garden was purposively built to conserve 
BBG aquatic plant specimen. However, as mentioned before, some of the aquatic plant species were also placed in other sites within the BBG such as Taman Upacara Adat Hindu Bali (TUAHB) Garden, Usada Garden and Cyathea Garden which contain $8 \%$ of the aquatic plant collection-number respectively (Figure 2). Another site that contains aquatic plant species was the Conservatory which contain $5 \%$ of the aquatic plant collection number (Figure 2).

Member of Acoraceae and Cyperaceae families were composed the most collection number with nine collection-number respectively (Figure 3). Most aquatic plant specimens were collected from Bali island $(84 \%)$ followed by plant specimen collected from Papua (6\%), Sumba and Timor with 5\% respectively (Figure 4). The aquatic plant collection site data shows us that BBG aquatic plant was collected only from Lesser Sunda Islands (Bali, Sumba and Timor) and Papua. As BBG objective is to conserve plant species from the eastern part of Indonesia, the botanic garden needs to collect aquatic plant species from another part of the region such as the Sulawesi and Moluccas.

Thirty-three aquatic plant collection-number in BBG were already identified until its species-level while four and one collection-number were identified until its genus level and as a hybrid plant specimen namely Nymphaea "Mrs. C.W. Word" respectively. Twenty-one species was consisting of the 33 collection-number identified until species level. The number of aquatic plants identified until its species level in BBG was almost the same as the number of aquatic species identified until its species level collected by the PBG with 17 species (Puspitasari and Irawanto, 2016). Of all plant species collected in BBG A. calamus was the most collected specimen with nine collection number, followed by A. ilicifolius, Cyperus involucratus, Nymphoides indica and Pontederia cordata with two collection number respectively (Figure 5).

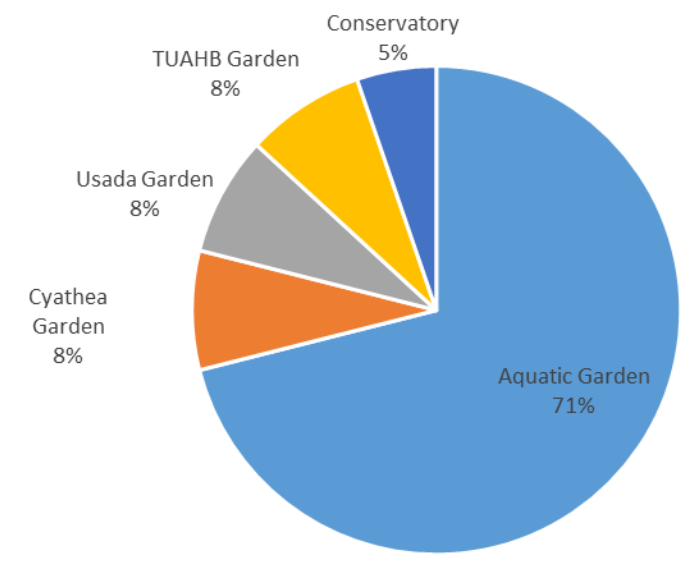

Figure 2. Aquatic Plant Species placement in Bali Botanic Garden
Jaccard similarity index calculation result shows that BBG and PBG aquatic plant species similarity is $11,76 \%$. Four common species were present in these two gardens, namely $A$. ilicifolius, $A$. calamus, Sagittaria lancifolia L. and Typha angustifolia. Low similarity value between BBG and PBG means that aquatic plant collection in these two botanic gardens was very different. The result was unsurprising as both botanic gardens were situated in two very different altitudes. The presence of common plant species may suggest those species' high tolerance toward temperature gradient.

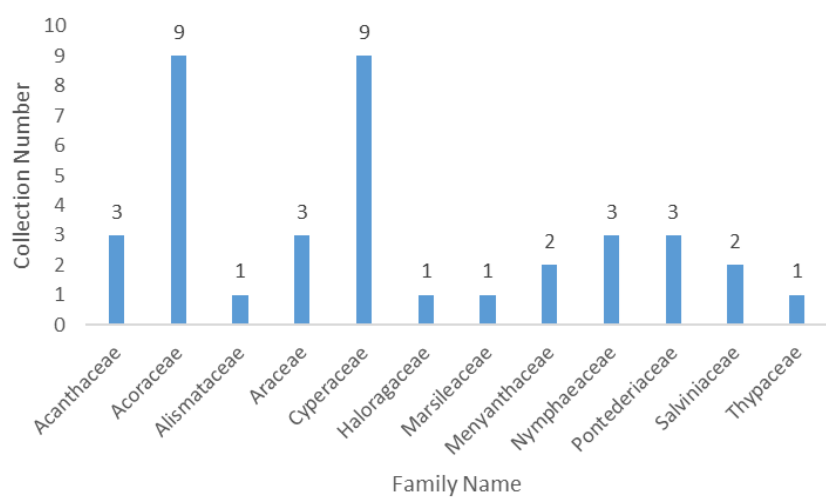

Figure 3. Aquatic Plant Family Collected in Bali Botanic Garden

Eleven aquatic plant species collected in BBG were listed in IUCN Red List as Least Concern (Table 2). Purnomo et al. (2015) stated that Indonesian Botanic Gardens were able to collect $24 \%$ and cultivated $25 \%$ of Indonesian threatened plant species which defined with its Vulnerable and above IUCN Red List status with BBG was mentioned to collect more than 20 of the listed species. The absence of aquatic plant species with IUCN Red List status of Vulnerable and above in BBG collection means that aquatic plant conservation in the garden was still not able yet to conserve aquatic plant species considered as high priority species for conservation. However,

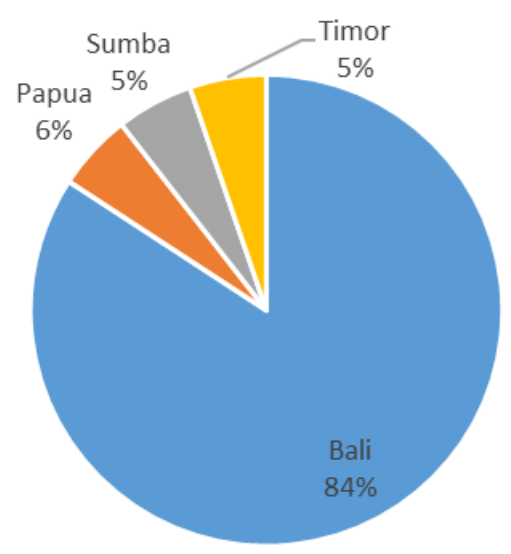

Figure 4. BBG Aquatic Plant Specimen Collection Sites 
conservation of aquatic plant species in BBG was still able to conserve plant species with decreasing population in the wild namely $A$. ebracteatus (Ellison et al., 2010). BBG was also able to conserve $A$. calamus which was important to traditionally cure several illnesses in Bali (Oktavia et al., 2017). The conservation effort of these species was important to safeguard the plant species from extinction.

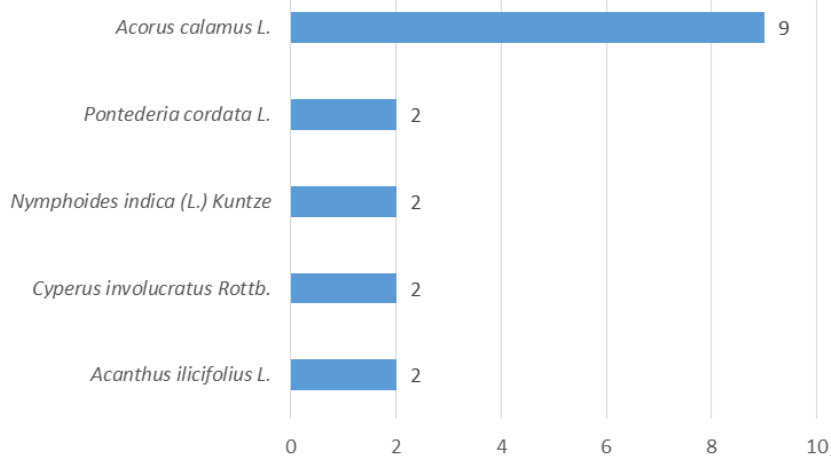

Figure 5. Five Most Collected Aquatic Plant Species in Bali Botanic Garden

\section{Phytoremediation Potential of BBG Aquatic} Plant Collection

Literatures studies suggested that 14 aquatic plant species collected in BBG was already assessed for its phytoremediation potential. The literatures also suggest that the plant species were able to accumulate 12 heavy metal pollutants, namely Arsenic (As), Cadmium (Cd), Cobalt (Co), Chromium (Cr), Cesium (Cs), Copper (Cu), Iron $(\mathrm{Fe})$, Mercury $(\mathrm{Hg})$, Manganese $(\mathrm{Mn})$, Nickel $(\mathrm{Ni})$, Lead $(\mathrm{Pb})$ and Zinc $(\mathrm{Zn})$. A complete list of aquatic plant species collected in BBG with metal pollutant that they able to accumulate based on our literatures study were presented in Table 3.

To the best of our knowledge, no research regarding aquatic plant species remediation potential has been done in BBG. This was unlike what happened in PBG which already researched the aquatic plant phytoremediation such as Irawanto et al. (2015) and Irawanto and Mangkoedihardjo (2015) which study the potential of $A$. ilicifolius and Coix lacryma-jobi to accumulate $\mathrm{Pb}$ and $\mathrm{Cd}$. Another example of an aquatic plant phytoremediation research conducted in PBG was the phytoremediation study of Lemna minor and Ceratophyllum demersum to $\mathrm{Pb}$ polluted water (Munandar et al., 2018) and the study of $S$. molesta and $P$. stratiotes phytoremediation toward $\mathrm{Cu}$ (Baroroh et al., 2018).

The current absence of aquatic plant species phytoremediation research in BBG open possibilities for future research in that field as phytoremediation potential of BBG aquatic plant species which not listed in Table 3, were probably not yet assessed. Even if the plant species phytoremediation potential were already assessed, further research in phytoremediator aquatic plant species will still important to conduct, as Gratão et al. (2005) and Vasavi et al. (2010) stated that research on aquatic plant mutant impact on the environment must be conducted as genetically modified phytoremediator plant species were possible to produce.

Invasive Alien Plant Species Status of BBG Aquatic Plant Collection

According to Setyawati et al. (2015) and Tjitrosoedirdjo et al. (2016), six aquatic plant species collected in BBG were listed as Invasive Alien Plant Species in Indonesia. Salviniaceae has contributed two species while Pontederiaceae, Cyperaceae, Haloragaceae and Araceae contributed one species respectively. Complete list of BBG aquatic plant species collection listed as invasive alien species was presented in Table 4 ..

Table 2. Conservation Status of Aquatic Species Collection in BBG Based on IUCN Red List

\begin{tabular}{lll}
\hline \multicolumn{1}{c}{ Species Name } & Conservation Status & \multicolumn{1}{c}{ Literatures } \\
\hline Acanthus ebracteatus Vahl & Least Concern & Ellison et al. (2010) \\
Acanthus ilicifolius L. & Least Concern & Juffe Bignoli (2011) \\
Acorus calamus L. & Least Concern & Lansdown (2014) \\
Azolla pinnata R. Br. & Least Concern & Gupta and Beentje (2018) \\
Cyperus haspan L. & Least Concern & Gupta and Lansdown (2018) \\
Cyperus papyrus L. & Least Concern & Beentje and Lansdown (2018) \\
Nymphaea pubescens Willd. & Least Concern & Gupta (2011) \\
Nymphoides indica (L.) Kuntze & Least Concern & Karuppasamy et al. (2019) \\
Pistia stratiotes L. & Least Concern & Lansdown (2019) \\
Schoenoplectiella mucronata (L.) J.Jung \& H.K.Choi & Least Concern & Lansdown (2013) \\
Typha angustifolia L. & Least Concern & Zhuang (2011) \\
\hline
\end{tabular}


Table 3. Phytoremediation Potential of BBG Aquatic Species Collection

\begin{tabular}{|c|c|c|}
\hline Plant Species & Pollutant & Literatures \\
\hline Acanthus ebracteatus Vahl & $\mathrm{Cu}$ & Wahwakhi et al. (2017) \\
\hline Acanthus ilicifolius L. & $\mathrm{Pb}, \mathrm{Cd}$ & Irawanto et al. (2015) \\
\hline \multirow[t]{4}{*}{ Acorus calamus L. } & $\mathrm{Cd}$ & Jeelani et al. (2017) \\
\hline & $\mathrm{Cu}$ & Lu et al. (2018); Sun et al. (2013) \\
\hline & $\mathrm{Cr}, \mathrm{Zn}, \mathrm{Fe}$ & Sun et al. (2013) \\
\hline & $\mathrm{Pb}$ & Ma et al. (2019) \\
\hline \multirow[t]{6}{*}{ Azolla pinnata R. Br. } & $\mathrm{Pb}$ & Mandakini et al. (2016) \\
\hline & $\mathrm{Cd}$ & $\begin{array}{l}\text { Mandakini et al. (2016); Rai (2008); Arora et al. (2004); Sood et } \\
\text { al. (2012); Talebi et al. (2019) }\end{array}$ \\
\hline & $\mathrm{Cr}$ & $\begin{array}{l}\text { Mandakini et al. (2016); Rai (2008); Arora et al. (2006); Sood et } \\
\text { al. (2012) }\end{array}$ \\
\hline & $\mathrm{Ni}$ & $\begin{array}{l}\text { Mandakini et al. (2016); Arora et al. (2004); Sood et al.; (2012); } \\
\text { Talebi et al. (2019) }\end{array}$ \\
\hline & $\mathrm{Hg}$ & $\begin{array}{l}\text { Rai (2008); Mishra et al. (2009); Rai and Tripathi (2009); Sood et } \\
\text { al. (2012) }\end{array}$ \\
\hline & $\mathrm{Zn}, \mathrm{Cu}$ & Talebi et al. (2019) \\
\hline \multirow[t]{2}{*}{ Cyperus involucratus Rottb. } & $\mathrm{Cu}, \mathrm{Zn}, \mathrm{Ni}, \mathrm{Mn}, \mathrm{Cd}, \mathrm{Pb}$ & Kaewtubtim et al. (2016) \\
\hline & $\mathrm{Cr}$ & Meeinkuirt et al. (2017); Kaewtubtim et al. (2016) \\
\hline Cyperus papyrus L. & As & Jomjun et al. (2011) \\
\hline Eichbornia crassipes (Mart.) & $\mathrm{Cu}$ & Lu et al. (2018); Hu et al. (2007); Sood et al. (2012) \\
\hline \multirow[t]{8}{*}{ Solms } & $\mathrm{Pb}$ & Ma et al. (2019) \\
\hline & $\mathrm{Hg}$ & Sood et al. (2012); Molisani et al. (2006); Skinner et al. (2007) \\
\hline & $\mathrm{Cd}$ & Mishra et al. (2007); Sood et al. (2012); Verma et al. (2008) \\
\hline & $\mathrm{Cr}$ & $\begin{array}{l}\text { Verma et al. (2008); Paiva et al. (2009); Sood et al. (2012); Mishra } \\
\text { and Tripathi (2009); Sumiahadi and Acar (2018) }\end{array}$ \\
\hline & $\mathrm{Ni}$ & Verma et al. (2008); Sood et al. (2012) \\
\hline & As & Alvarado et al. (2008); Sumiahadi and Acar (2018) \\
\hline & $\mathrm{Zn}$ & Mishra and Tripathi (2009); Sumiahadi and Acar (2018) \\
\hline & Cs, Co & Saleh (2012); Sumiahadi and Acar (2018) \\
\hline Myriophyllum aquaticum & $\mathrm{Ni}, \mathrm{Pb}, \mathrm{Zn}$ & Harguinteguy et al. (2015); Harguinteguy et al. (2013) \\
\hline (Vell.) Verdc. & $\mathrm{Co}, \mathrm{Cu}, \mathrm{Fe}, \mathrm{Mn}$ & Harguinteguy et al. (2013) \\
\hline Nymphaea pubescens Willd. & $\mathrm{Pb}, \mathrm{Zn}, \mathrm{Co}, \mathrm{Cd}$ & Kabeer et al. (2014) \\
\hline \multirow[t]{7}{*}{ Pistia stratiotes L. } & $\mathrm{Cu}$ & Lu et al. (2018); Baroroh et al. (2018) \\
\hline & $\mathrm{Hg}$ & $\begin{array}{l}\text { Mishra et al. (2009); Molisani et al. (2006); Skinner et al. (2007); } \\
\text { Sood et al. (2012) }\end{array}$ \\
\hline & $\mathrm{Cr}$ & $\begin{array}{l}\text { Verma et al. (2008); Mufarrege et al. (2010); Sood et al. (2012); } \\
\text { Serang et al. (2018); Akter et al. (2014); Sumiahadi and Acar } \\
\text { (2018) }\end{array}$ \\
\hline & $\mathrm{Cd}$ & $\begin{array}{l}\text { Verma et al. (2008); Sood et al. (2012); Das et al. (2014); Sumi- } \\
\text { ahadi and Acar (2018) }\end{array}$ \\
\hline & $\mathrm{Ni}$ & Verma et al. (2008); Mufarrege et al. (2010); Sood et al. (2012) \\
\hline & $\mathrm{Zn}$ & Mufarrege et al. (2010); Sood et al. (2012) \\
\hline & As & Sumiahadi and Acar (2018); Farnese et al. (2014) \\
\hline Pontederia cordata L. & $\mathrm{Cr}, \mathrm{Fe}, \mathrm{Cu}, \mathrm{Zn}$ & Sun et al. (2013) \\
\hline Sagittaria lancifolia L. & $\mathrm{Cr}$ & Serang et al. (2018) \\
\hline \multirow[t]{4}{*}{ Salvinia adnata Desv. } & $\mathrm{Pb}$ & $\begin{array}{l}\text { George and Gabriel (2017); Kumari et al. (2017); Ranjitha et al. } \\
\text { (2016) }\end{array}$ \\
\hline & $\mathrm{Hg}$ & Kumari et al. (2017) \\
\hline & $\mathrm{Cr}, \mathrm{Cd}$ & Ranjitha et al. (2016) \\
\hline & $\mathrm{Cu}$ & Ranjitha et al. (2016); Baroroh et al. (2018) \\
\hline \multirow[t]{2}{*}{ Typha angustifolia L. } & $\mathrm{Mn}$ & Kaewtubtim et al. (2016) \\
\hline & $\begin{array}{l}\mathrm{Cr}, \mathrm{Zn}, \mathrm{Cu} \\
\text { As }\end{array}$ & $\begin{array}{l}\text { Bareen and Khilji (2008); Sood et al. (2012) } \\
\text { Jomjun et al. (2011) }\end{array}$ \\
\hline
\end{tabular}


J. Tropical Biodiversity Biotechnology, vol. 05 (2020), $16-26$

Table 4. Aquatic Species Collection of BBG Listed as Invasive Alien Plant Species in Indonesia

\begin{tabular}{|c|c|c|c|}
\hline Species Name & Family & Origin & Literatures \\
\hline Arolla pinnata R. Br. & Salviniaceae & Tropical Asia & Setyawati et al. (2015) \\
\hline Eichhornia crassipes (Mart.) Solms & Pontederiaceae & Tropical South America & $\begin{array}{l}\text { Setyawati et al. (2015); } \\
\text { Tjitrosoedirdjo et al. (2016) }\end{array}$ \\
\hline Fimbristylis umbellaris (Lam.) Vahl. & Cyperaceae & South East Asia & Setyawati et al. (2015) \\
\hline $\begin{array}{l}\text { Myriophyllum aquaticum (Vell.) } \\
\text { Verdc. }\end{array}$ & Haloragaceae & South America & Setyawati et al. (2015) \\
\hline Pistia stratiotes $\mathrm{L}$. & Araceae & Africa or South America & $\begin{array}{l}\text { Setyawati et al. (2015); } \\
\text { Tjitrosoedirdjo et al. (2016) }\end{array}$ \\
\hline Salvinia adnata Desv. & Salviniaceae & South America & $\begin{array}{l}\text { Setyawati et al. (2015); } \\
\text { Tjitrosoedirdjo et al. (2016) }\end{array}$ \\
\hline
\end{tabular}

Eichbornia crassipes, $P$. stratiotes and $S$. adnata were considered as three of the 75 important invasive alien plant species in Indonesia by Tjitrosoedirdjo et al. (2016). All the three species were also listed as important aquatic invasive alien plant species by Tjitrosoedirdjo (2005). E. crassipes was even listed by Lowe et al. (2000) as one of the worst invasive alien plant species. Originated from the Tropical South America E. crassipes was first introduced in 1894 to Bogor Botanic Garden and now present throughout Indonesia (Tjitrosoedirdjo et al., 2016; Hulme 2011; Setyawati et al., 2015). As with the E. crassipes, P. stratiotes was also placed in the BBG Aquatic Garden and also widely distributed in Indonesia with Africa or South America were considered as probable origin region for the species (Setyawati et al., 2015; Tjitrosoedirdjo et al., 2016). Both E. crassipes and P. stratiotes were firstly introduced to BBG in 2004 while Darma et al. (2017) reported the present of both plant species in Tri-Danau which consist of three lakes near BBG namely the Beratan, Buyan and Tamblingan.

Unlike the two previously mentioned important aquatic invasive alien plant species collected in BBG, S. adnata was placed in Cyathea Garden. Popularly known also by its synonym name of $S$. molesta, the plant species was originated from South America and distributed throughout Indonesia (Setyawati et al., 2015; Tjitrosoedirdjo et al., 2016). S. adnata was firstly introduced to BBG in 2012. The introduced specimens were collected from Buyan Lake. This was following Darma et al. (2017) which reported that a large portion of Buyan Lake was covered by $S$. adnata. However, the lake revitalization program carried out by the government was able to free most of the lake water bodies previously occupied by aquatic weeds including $S$. adnata.

As data of the three species, first present in the Tri-Danau region was absent, we were unable to conclude whether the $P$. stratiotes and E. crassipes specimen in the lakes were actually came from the BBG. However, careful management of all invasive aquatic plant species which presented in BBG collection was needed to prevent the invasive plant species escape. Management of aquatic invasive alien plant species in BBG could be done as suggested by Heywood and Sharrock (2013) in the European Code of Conduct for Botanic Gardens on Invasive Alien Species.

\section{CONCLUSION}

Aquatic plant species conservation in BBG is able to conserve plant species listed by IUCN Red List, as well as aquatic plant with phytoremediation and invasive potential. Eleven species of aquatic plant species in BBG are listed as Least Concern by IUCN Red List, fourteen species have phytoremediation potential and six species are listed as invasive alien plant species. The majority of the aquatic plant species are collected from Bali Island. Resulted data from this study can be used as a baseline data to conduct collection-based research in the future. On the other hand, this data also provides the garden manager with invasiveness status of aquatic plant collection to be monitored accordingly. The list also suggests that BBG should explore more aquatic plant species from another island in the eastern Indonesia region to enrich its collections.

\section{ACKNOWLEDGMENTS}

The author would like to thanks the Bali Botanic Garden Registration Unit for providing the plant collection data. Gratitude was also given to all of the botanic garden researchers for the help and discussion during this manuscript writing process as well as to Rajif Iryadi for providing the BBG map.

\section{REFERENCES}

Akter, S., Afrin, R., Mia, M.Y. \& Hossen, M.Z., 2014, Phytoremediation of Chromium (Cr) from Tannery Effluent by Using Water Lettuce (Pistia stratiotes), ASA University Review 8(2), 149-156. 
Alkorta, I. \& Garbisu, C., 2001, Phytoremediation of organic contaminants in soils, Bioresource technology 79(3), 273-276.

Alvarado, S., Guédez, M., Lué-Merú, M.P., Nelson, G., Alvaro, A., Jesús, A.C. \& Gyula, Z., 2008, Arsenic removal from waters by bioremediation with the aquatic plants Water Hyacinth (Eichhornia crassipes) and Lesser Duckweed (Lemna minor), Bioresource Technology 99(17), 8436-8440.

Arora, A., Saxena, S. \& Sharma, D.K., 2006, Tolerance and phytoaccumulation of chromium by three Azolla species, World Journal of Microbiology and Biotechnology 22(2), 97100.

Arora, A., Sood, A. \& Singh, P.K., 2004, Hyperaccumulation of cadmium and nickel by Arolla species, Indian Journal of Plant Physiology 9(3), 302-304.

Bareen, F. \& Khilji, S., 2008, Bioaccumulation of metals from tannery sludge by Typha angustifolia L., African Journal of Biotechnology 7 (18), 3314-3320.

Baroroh, F., Handayanto, E. \& Irawanto, R., 2018, Fitoremediasi Air Tercemar Tembaga (Cu) Mengguanakan Salvinia molesta dan Pistia stratiotes Serta Pengaruhnya Terhadap Pertumbuhan Tanaman Brassica rapa, Jurnal Tanah dan Sumberdaya Lahan 5(1), 689-700.

Beentje, H.J. \& Lansdown, R.V., 2018, Cyperus papyrus, The IUCN Red List of Threatened Species 2018: e.T164158A120152171, http:// dx.doi.org/10.2305/IUCN.UK.20182.RLTS.T164158A120152171.en., Downloaded on 12 August 2019.

Bilz, M., Kell, S.P., Maxted, N. \& Lansdown, R.V., 2011, European Red List of Vascular Plants, Luxembourg: Publications Office of the European Union.

Darma, I.D.P., Priyadi, A. \& Sujarwo, W., 2017, Analisis Vegetasi Tumbuhan Air Di Kawasan Tri Danau (Beratan, Buyan, Tamblingan) Bali, LIMNOTEK-Perairan Darat Tropis di Indonesia 24(1), 36-43.

Das, S., Goswami, S. \& Talukdar, A.D., 2014, A study on cadmium phytoremediation potential of water lettuce, Pistia stratiotes L., Bulletin of environmental contamination and toxicology 92(2), 169-174.
Ellison, J., Koedam, N.E., Wang, Y., Primavera, J., Jin Eong, O., Wan-Hong Yong, J. \& Ngoc Nam, V., 2010, Acanthus ebracteatus, The IUCN Red List of Threatened Species 2010: e.T178832A7621003, http: / / dx.doi.org/10.2305/IUCN.UK.20102.RLTS.T178832A7621003.en. Downloaded on 12 August 2019.

Farnese, F.S., Oliveira, J.A., Lima, F.S., Leão, G.A., Gusman, G.S. \& Silva, L.C., 2014, Evaluation of the potential of Pistia stratiotes L. (water lettuce) for bioindication and phytoremediation of aquatic environments contaminated with arsenic, Brazilian Journal of Biology 74(3), S108-S112.

George, G.T \& Gabriel, J.J., 2017, Phytoremediation of Heavy Metals from Municipal Waste Water by Salvinia molesta Mitchell, Haya: Saudi J. Life Sci. 2(3), 108-115.

Gratão, P.L., Prasad, M.N.V., Cardoso, P.F., Lea, P.J. \& Azevedo, R.A., 2005, Phytoremediation: green technology for the clean up of toxic metals in the environment, Brazilian Journal of Plant Physiology 17(1), 53-64.

Gupta, A.K. \& Beentje, H.J., 2018, Azolla pinnata, The IUCN Red List of Threatened Species 2018: e.T168790A120142955, http:// dx.doi.org/10.2305/IUCN.UK.20182.RLTS.T168790A120142955.en, Downloaded on 12 August 2019.

Gupta, A.K. \& Lansdown, R.V., 2018, Cyperus haspan, The IUCN Red List of Threatened Species 2018: e.T168969A1258665, http:// dx.doi.org/10.2305/IUCN.UK.20182.RLTS.T168969A1258665.en, Downloaded on 12 August 2019.

Gupta, A.K., 2011, Nymphaea pubescens, The IUCN Red List of Threatened Species 2011: e.T168878A6544567, http:// dx.doi.org/10.2305/IUCN.UK.20111.RLTS.T168878A6544567.en, Downloaded on 12 August 2019.

Hadimuljono M.B., Sudarmonowati E., Widyatmoko D., Rukmana D., Witono J.R., Purnomo D.W., Solihah S.M., Puspaningtyas D.M., Atmawidjaja E.S. \& Chusaini H.A., 2014, Roadmap pembangunan kebun raya non perkotaan tahun 2015-2019: Sebuah sinergi konservasi dan pembangunan ekonomi, Pusat Konservasi Tumbuban Kebun Raya LIPI, Bogor. ISBN: 978-979-8539-59-6 
Harguinteguy, C.A., Pignata, M.L. \& FernándezCirelli, A., 2015, Nickel, lead and zinc accumulation and performance in relation to their use in phytoremediation of macrophytes Myriophyllum aquaticum and Egeria densa, Ecological engineering 82, 512-516.

Harguinteguy, C.A., Schreiber, R. \& Pignata, M.L., 2013, Myriophyllum aquaticum as a biomonitor of water heavy metal input related to agricultural activities in the Xanaes River (Córdoba, Argentina), Ecological indicators 27, 816.

Heywood, V.H. \& Sharrock, S., 2013, European Code of Conduct for Botanic Gardens on Invasive Alien Species, Council of Europe Strasbourg, Botanic Gardens Conservation International, Richmond, ISBN 10: 1-90516448-3 ISBN 13: 978-1-905164-48-6.

Hu, C., Zhang, L., Hamilton, D., Zhou, W., Yang, T. \& Zhu, D., 2007, Physiological responses induced by copper bioaccumulation in Eichhornia crassipes (Mart.), Hydrobiologia 579(1), 211-218.

Hulme, P.E., 2011, Addressing the threat to biodiversity from botanic gardens, Trends in Ecology \& Evolution 26(4),168-174.

Irawanto, R. \& Mangkoedihardjo, S., 2015, Fitoforensik Logam Berat ( $\mathrm{Pb}$ dan $\mathrm{Cd}$ ) Pada Tumbuhan Akuatik (Acanthus ilicifolius and Coix lacryma-jobi), Jurnal Purifikasi 15(1), 53-66.

Irawanto, R., Hendrian, R. \& Mangkoedihardjo, S., 2015, Konsentrasi Logam Berat (Pb dan Cd) pada Bagian Tumbuhan Akuatik Acanthus ilicifolius (Jeruju), Prosiding KPSDA, 1(1), SP003 $-022$.

Ismail, S.N., Hamid, M.A. \& Mansor, M., 2018, Ecological correlation between aquatic vegetation and freshwater fish populations in Perak River, Malaysia, Biodiversitas Journal of Biological Diversity 19(1), 279-284.

IUCN., 2019, The IUCN Red List of Threatened Species, Version 2019-2, ISSN 2307-8235, accessed 29th July 2019, from https://www.iucnRed List.org

Jeelani, N., Yang, W., Xu, L., Qiao, Y., An, S. \& Leng, X., 2017, Phytoremediation potential of Acorus calamus in soils co-contaminated with cadmium and polycyclic aromatic hydrocarbons, Scientific reports 7(1), 1-9.

Jha, K.K., 2013, Aquatic food plants and their consumer birds at Sandi Bird Sanctuary, Hardoi, Northern India, Asian Journal of Conservation Biology 2(1), 30-43.
Jomjun, N., Siripen, T., Maliwan, S., Jintapat, N., Prasak, T., Somporn, C. \& Petch, P., 2011, Phytoremediation of arsenic in submerged soil by wetland plants, International journal of phytoremediation 13(1), 35-46.

Juffe Bignoli, D., 2011, Acanthus ilicifolius, The IUCN Red List of Threatened Species 2011: e.T168780A6536949, http:/ / dx.doi.org/10.2305/IUCN.UK.2011 1.RLTS.T168780A6536949.en, Downloaded on 12 August 2019.

Kabeer, R., Varghese, R., Kannan, V.M., Thomas, J.R. \& Poulose, S.V., 2014, Rhizosphere bacterial diversity and heavy metal accumulation in Nymphaea pubescens in aid of phytoremediation potential, Journal of Bioscience \& Biotechnology 3(1), 89-95.

Kaewtubtim, P., Meeinkuirt, W., Seepom, S. \& Pichtel, J., 2016, Heavy metal phytoremediation potential of plant species in a mangrove ecosystem in Pattani Bay, Thailand, Applied Ecology and Environmental Research 14(1), 367-382.

Karuppasamy, S., Rao, M.L.V., Beentje, H.J. \& Lansdown, R.V., 2019, Nymphoides indica, The IUCN Red List of Threatened Species 2019: e.T168916A120213259, http:// dx.doi.org/10.2305/IUCN.UK.20192.RLTS.T168916A120213259.en, Downloaded on 12 August 2019.

Keller, R.P., Masoodi, A. \& Shackleton, R.T., 2018, The impact of invasive aquatic plants on ecosystem services and human well-being in Wular Lake, India, Regional environmental change 18(3), 847-857.

Kuehne, L.M., Olden, J.D. \& Rubenson, E.S., 2016, Multi-trophic impacts of an invasive aquatic plant, Freshwater Biology 61(11), 1846-1861.

Kumari, S., Kumar, B. \& Sheel, R., 2017, Biological control of heavy metal pollutants in water by Salvinia molesta, Int J Curr Microbiol App Sci 6(4), 2838-2843.

Lacoul, P. \& Freedman, B., 2006, Environmental influences on aquatic plants in freshwater ecosystems, Environmental Reviews 14(2), 89136.

Lansdown, R.V., 2013, Schoenoplectus mucronatus, The IUCN Red List of Threatened Species 2013: e.T164086A13553540, http:// dx.doi.org/10.2305/IUCN.UK.20131.RLTS.T164086A13553540.en, Downloaded on 12 August 2019. 
Lansdown, R.V., 2014, Acorus calamus, The IUCN Red List of Threatened Species 2014: e.T168639A43116307, http:// dx.doi.org/10.2305/IUCN.UK.20141.RLTS.T168639A43116307.en, Downloaded on 12 August 2019.

Lansdown, R.V., 2019, Pistia stratiotes, The IUCN Red List of Threatened Species 2019: e.T168937A120126770, http:// dx.doi.org/10.2305/IUCN.UK.20192.RLTS.T168937 A 120126770 .en, Downloaded on 12 August 2019.

Lowe, S., Browne, M., Boudjelas, S. \& De Poorter, M., 2000, 100 of the world's worst invasive alien species: a selection from the global invasive species database (Vol. 12),Invasive Species Specialist Group, Auckland

Lu, D., Huang, Q., Deng, C. \& Zheng, Y., 2018, Phytoremediation of Copper Pollution by Eight Aquatic Plants, Polish Journal of Environmental Studies 27(1), 175-181

Ma, Q., Peng, Y., Zhang, J. \& Ji, M., 2019, Enrichment Capacity of Lead in Water by Aquatic Plants, Polish Journal of Environmental Studies 28(4), 2745-2754.

Mandakini, L.L.U., Bandara, N.J.G.J. \& Gunawardana, D., 2016, A study on the Phytoremediation Potential of Azolla pinnata under laboratory conditions, Journal of Tropical Forestry and Environment 6(1), 36-49.

Meeinkuirt, W., Kaewtubtim, P., Seepom, S. \& Pichtel, J., 2017, Metal uptake and accumulation by mangrove plant species in Pattani Bay, Thailand, Proceedings of the 3rd World Congress on New Technologies (NewTech'17).

Mishra, K.K., Rai, U.N. \& Prakash, O., 2007, Bioconcentration and phytotoxicity of $\mathrm{Cd}$ in Eichhornia crassipes, Environmental monitoring and assessment 130(1-3), 237-243.

Mishra, V.K. \& Tripathi, B.D., 2009, Accumulation of chromium and zinc from aqueous solutions using water hyacinth (Eichhornia crassipes), Journal of Hazardous Materials 164(23), 1059-1063.

Mishra, V.K., Tripathi, B.D. \& Kim, K.H., 2009, Removal and accumulation of mercury by aquatic macrophytes from an open cast coal mine effluent, Journal of Hazardous Materials 172(2-3), 749-754.

Molisani, M.M., Rocha, R., Machado, W., Barreto, R.C. \& Lacerda, L.D., 2006, Mercury contents in aquatic macrophytes from two reservoirs in the Paraíba do Sul: Guandú river system, SE Brazil, Brazilian Journal of Biology 66(1A), 101107.
Mueller-Dombois, D \& Ellenberg, H., 2016, Ekologi Vegetasi Tujuan dan Metode, Alih Bahasa K. Kartawinata \& R. Abdulhadi LIPI Press and Yayasan Pustaka Obor Indonesia, pp. 236237, Jakarta-Indonesia.

Mufarrege, M.M., Hadad, H.R. \& Maine, M.A., 2010, Response of Pistia stratiotes to heavy metals (Cr, Ni, and $\mathrm{Zn}$ ) and phosphorous, Archives of environmental contamination and toxicology 58(1), 53-61.

Munandar, A.A., Kusuma, Z., Prijono, S. \& Irawanto, R., 2018, Fitoremediasi Air Tercemar Timbal $(\mathrm{Pb})$ Dengan Lemna minor Dan Ceratophyllum demersum Serta Pengaruhnya Terhadap Pertumbuhan Lactuca sativa, Jurnal Tanah dan Sumberdaya Lahan 5(2), 867-874.

Oktavia, G.A.E., Darma, I.D.P. \& Sujarwo, W., 2017, Studi etnobotani tumbuhan obat di kawasan sekitar Danau Buyan-Tamblingan, Bali, Buletin Kebun Raya 20(1), 1-16.

Paiva, L.B., de Oliveira, J.G., Azevedo, R.A., Ribeiro, D.R., da Silva, M.G. \& Vitória, A.P., 2009, Ecophysiological responses of water hyacinth exposed to $\mathrm{Cr} 3+$ and Cr6+, Environmental and Experimental Botany 65 (2-3), 403-409.

Peuke, A.D. \& Rennenberg, H., 2005, Phytoremediation, EMBO reports 6(6), 497 501.

Purnomo, D.W., Magandhi, M., Kuswantoro, F., Risna, R.A. \& Witono, J.R., 2015, Pengembangan koleksi tumbuhan kebun raya daerah dalam kerangka strategi konservasi tumbuhan di Indonesia, Buletin Kebun Raya 18 (2), 111-124.

Puspitasari, D. \& Irawanto, R., 2016, Fitoremediasi Limbah Domestik Dengan Tumbuhan Akuatik Mengapung Di Kebun Raya Purwodadi, Prosiding Seminar Nasional FTP UB Malang, 1-10.

Rai, P.K. \& Tripathi, B.D., 2009, Comparative assessment of Azolla pinnata and Vallisneria spiralis in $\mathrm{Hg}$ removal from G.B. Pant Sagar of Singrauli Industrial region, India, Environmental Monitoring and Assessment 148(1-4), 75-84.

Rai, P.K., 2008, Phytoremediation of $\mathrm{Hg}$ and $\mathrm{Cd}$ from industrial effluents using an aquatic free floating macrophyte Azolla pinnata, International journal of phytoremediation 10 (5), 430-439.

Ranjitha J., Raj, A., Kashyap, R., Vijayalakshmi, S., \& Donatus, M., 2016, Removal of heavy metals from industrial effluent using Salvinia molesta, Int. J. Chem Tech. Res. 9(5), 608- 613. 
Saleh, H.M., 2012, Water hyacinth for phytoremediation of radioactive waste simulate contaminated with cesium and cobalt radionuclides, Nuclear Engineering and Design 242, 425-432.

Serang, L.K.O., Handayanto, E. \& Rindyastuti, R., 2018, Fitoremediasi Air Tercemar Logam Kromium Dengan Menggunakan Sagittaria lancifolia dan Pistia stratiotes Serta Pengaruhnya Terhadap Pertumbuhan Kangkung Darat (Ipomea reptans), Jurnal Tanah dan Sumberdaya Laban 5(1), 739-746.

Setyawati, T., Narulita, S., Bahri I.P., \& Raharjo G.T., 2015, A Guide Book to Invasive Plant Species in Indonesia. in T. Partomihardjo, S. Tjitrosoedirdjo \& Sunaryo (eds.). Research, Development and Innovation Agency. Ministry of Environment and Forestry. Bogor -Indonesia. ISBN: 978-979-8452-66-6

Skinner, K., Wright, N. \& Porter-Goff, E., 2007, Mercury uptake and accumulation by four species of aquatic plants, Environmental pollution 145(1), 234-237.

Sood, A., Uniyal, P.L., Prasanna, R. \& Ahluwalia, A.S., 2012, Phytoremediation potential of aquatic macrophyte, Azolla, Ambio, 41(2), 122137.

Sumiahadi, A. \& Acar, R., 2018, A review of phytoremediation technology: heavy metals uptake by plants, IOP Conference Series: Earth and Environmental Science 142(1), 1-9.

Sun, H., Wang, Z., Gao, P. \& Liu, P., 2013, Selection of aquatic plants for phytoremediation of heavy metal in electroplate wastewater, Acta physiologiae plantarum 35(2), 355-364.
Talebi, M., Tabatabaei, B.E.S. \& Akbarzadeh, H., 2019, Hyperaccumulation of $\mathrm{Cu}, \mathrm{Zn}, \mathrm{Ni}$, and $\mathrm{Cd}$ in Arolla species inducing expression of methallothionein and phytochelatin synthase genes, Chemosphere 230, 488-497.

The Plant List., 2013, The Plant List a Working List of All Plant Species, Version 1.1. Published on the Internet, accessed 29th July 2019 from http:/ /www.theplantlist.org/

Tjitrosoedirdjo, S.S., 2005, Inventory of the invasive alien plant species in Indonesia, BIOTROPLAThe Southeast Asian Journal of Tropical Biology 25, 60-73.

Tjitrosoedirdjo, S.S., Mawardi I., \& Tjitrosoedirdjo S., 2016, 75 Important Invasive Alien Plant Species in Indonesia, SEAMEO BIOTROP. Bogor-Indonesia. ISBN: 978-979-8275-49-4.

Vasavi, A., Usha, R. \& Swamy, P.M., 2010, Phytoremediation-an overview review, J Ind Pollut Control 26(1),83-88.

Verma, V.K., Tewari, S. \& Rai, J.P.N., 2008, Ion exchange during heavy metal bio-sorption from aqueous solution by dried biomass of macrophytes, Bioresource Technology 99(6), 19321938.

Wahwakhi, S., Kusmana, C. \& Iswantini, D., 2017, Potency of Acanthus ilicifolius as phytoremediation agent against copper pollution in Jagir River estuary, Wonorejo Village, Surabaya, Indonesia, Aquaculture, Aquarium, Conservation \& Legislation Bioflux 10 (5), 1186-1197.

Zhuang, X., 2011, Typha angustifolia, The IUCN Red List of Threatened Species 2011: e.T164199A5772487, http:// dx.doi.org/10.2305/IUCN.UK.2011 1.RLTS.T164199A5772487.en, Downloaded on 12 August 2019. 